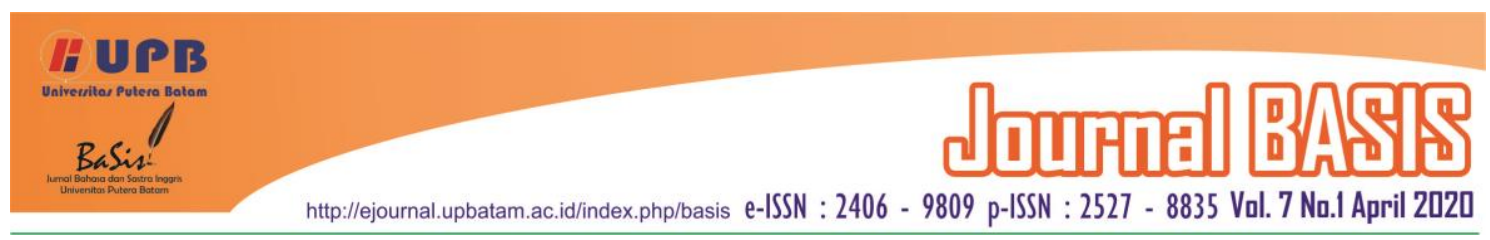

\title{
A TRANSLATION ANALYSIS ON THE INDONESIAN VERSION OF “DEAR GOD” BY AVENGED SEVENFOLD
}

\author{
Nanda Yunisa \\ Airlangga University (UNAIR), Surabaya, Indonesia \\ nanda_yunisa@yahoo.com
}

\begin{abstract}
The object of this research is the lyrics of the song Avenged Sevenfold Dear God Indonesian Version. This research discussed the translation method of the Indonesian version of the song of Dear God and aimed at finding out the translator's ideology in the translation of the Indonesian version of the song of Dear God in terms of the theory of domestication and foreignization. This study used qualitative approach with qualitative descriptive methods. The theories used in this study were theories from Newmark and Venuti, and also other theories to support this research. In this study, translators were found using the translation method which is oriented to the source text. In addition, the domestication technique looked dominant in the translation of the songs because according to Newmark (1988) this technique was the most free technique to do because it focused on the effectiveness of the target language by updating what has been provided in the source text. Thus, the translation of the Indonesian version of the song Dear God emphasizes the ideology of domestication. The result of this study indicated that translators tend to use translation methods that are oriented to the language of the target text. Additionally, it was found that the domestication technique appeared dominantly in the translation of the Indonesian version of Dear God song.
\end{abstract}

Keywords: Avenged Sevenfold; Domestication; Foreignization; Song; Translation.

\section{INTRODUCTION}

Music has an appeal and can provide education to the community. In everyday life, consciously or unconsciously humans are always associated with music, one of them with songs. In human life, song is not only a means to entertain, but also has a message and ideology to be conveyed through the lyrics. According to Carbaugh (1993) a song is a picture of an individual or a group constructed so as to present a particular cultural environment in society. As one of the cultural products, the songs that are scattered have certain cultural characteristics, one of which is song translation.

The translator has an important influence in connecting the original song with the translated song. This is in line with the statement of Munday and Hatim (2004) which said that translation is a phenomenon that has an important influence on daily life in society. With the translation, each individual can know various things that have not been known before, in this case the truth about the original text influenced by the translator which includes the process of interpreting words, ideas, and meanings from one culture to another. As Ruben and Rosman put it in their book entitled Translating Cultures: Perspectives on Translation and Anthropology (2003) that the process of translation is a process of "cross-cultural understanding."

With the importance of translating into everyday life in society, translators are interested in researching and 
analyzing the translation of the song Dear God by the American band Avenged Sevenfold. This song was released on June 15, 2008 as the fourth single on the album Avenged Sevenfold. Researchers are interested in researching this song because this song is a song that is very popular in the world. This is evidenced by the number of YouTube viewers of this song until December 14, 2019 of 115,098,848 and 52,856 comments. It is not surprising this song was made with many versions. One of them is the Indonesian version. The Indonesian version of Dear God is the result of the creativity of a fan named Syahid Mahyuddin. He is one of many of The Fallen (a term for Avenged Sevenfold fans) who were disappointed because of the failure of the Avenged Sevenfold concert in Indonesia in 2012. Creatively, Syahid made a song by one of Avenged Sevenfold's popular songs, Dear God, to become the Indonesian version.

The Indonesian version of Dear God song sung by Syahid has a number of YouTube viewers as of December 14, 2019 totaling 2,660,596 and 3,286 comments. In addition, due to the acceptance of the Indonesian version of Dear God in the community, many Syahid's steps were followed by other YouTubers to sing the Indonesian version of this song again.

In translating songs, translators will experience various difficulties. This is because in translating songs, translators must adjust the beats. That is, in choosing diction, the translator must adjust it to the melody of the original song. Not only that, the main problem in translation is the compatibility between the source text and the target text. This is in line with House (2000) which said that translation is the equivalent of the source text with the target text.

Seeing this phenomenon, this research needed to be done. This was because it involves translation and arises the question whether the song's translation is in accordance with the source material. Based on the background that has been described, the formulation of the problems that would be answered in this study are:

1. What is the Indonesian version of the Dear God song translation method?

2. Is the ideology of translators in translating the Indonesian version of Dear God in terms of the theory of domestication and foreignization?

\section{LITERATURE REVIEW}

2.1. Theory of the Research

In this study the concept of translation techniques proposed by Peter Newmark (1997) was considered fit for the study. An additional approach which supported the research is the theory of domestication and foreignization by Venuti.

Newmark mentioned eight types of translation methods which were divided into two groups, namely source language oriented (SL) and target language oriented (TL): This translation method was also known as V Diagram (Newmark, 1997).

\begin{tabular}{lll}
$\begin{array}{l}\text { Source language } \\
\text { oriented (SL) }\end{array}$ & $\begin{array}{l}\text { Target } \\
\text { oriented (TL) }\end{array}$ & language \\
\hline
\end{tabular}

\begin{tabular}{|c|c|}
\hline Word-for-word & Adaptation \\
\hline Hanstation & Free translation \\
\hline Literal translation & Idiomatic translation \\
\hline $\begin{array}{l}\text { Faithful translation } \\
\text { Semantic } \\
\text { translation }\end{array}$ & $\begin{array}{l}\text { Communicative } \\
\text { translation }\end{array}$ \\
\hline
\end{tabular}


In translation, the term 'ideology' is defined as a principle or belief on whether a translation product is deemed "right or wrong" (Hoed, 2003). A translation is considered true if it contains the source language text, conforms with the rules, norms, and culture which apply to the target language. The other side of the assumption argues that translation is only based on the acceptance level of the target language. From these two assumptions, two ideologies of translation emerged, namely foreignization and domestication. That approach was used to show the results of the Indonesian version of Dear God song whether it is more concerned with the source text or the target text.

\subsection{Previous Study}

Research on song lyric analysis was pretty much found on some of the investigations, one study was conducted by Geofani Anggasta and M. Sally H. L. Pattinasarany's (2013) with the title Analysis of the Lexical Equivalent Translation Technique of American Popular Songs in German. This study showed that the most widely used translation technique was the translation of secondary and figurative meanings.

Furthermore, the research of Hwayeon Jong, I Gede Oeinada and Ni Putu Luhur Wedayanti (2016) entitled Procedure and Method of Translation of Song Lyrics in Frozen Films showed the four categories of translation methods by Newmark (1988). The translation method applied tends to be oriented to the target text. Next is the research of N.L.A.P.Utari, G.S.Hermawan, I.W.Sadyana (2017) entitled Analysis of Grammatical Translation and Slamming Techniques in AKB48 song lyrics. This study showed 7 types of translation techniques applied in 77 translation units (UT) in the result. Furthermore, grammatical leanness was also found. This is because in the process of translating AKB48 song lyrics, the translator tried to maintain the value of the sense of the structure of the source text in the target text. This desire made the translator intentionally ignored the grammatical rules in the target text so that there appeared some incongruity in the structure.

$$
\text { Zakrimal's research (2019) }
$$

entitled Translation Shift of Google Translate Program in Translating Sport News on LINE Daily Kompas. This study used Catford's translation theory, namely structure shift, class shift, unit shift, and intra-system shift from Indonesian (as the source language) into English (as the target language). This theory was used to determine the type of translation shift in sports articles originating from the Kompas daily news media, but the difference between this research and the one conducted by Zakrimal is on the object and theory used.

Based on the aforementioned previous studies, this study has the same object of study, namely song lyrics. However what distinguishes this research from previous research is the theory used to analyze the object of study. This study analyzed the translation of the Indonesian version of the song Dear God using Newmark and Venuti theories.

\section{RESEARCH METHOD}

This study employed a qualitative approach with qualitative descriptive methods. Data and Research data sources were Indonesian version of Dear God song lyrics. Analysis and data collection techniques used were documents or archives by identifying the translation methodology and 
ideology used. Procedurally, the analysis of the research data was as follows: (1) the researcher displayed the data in the form of the translation of the Dear God song Indonesian version (2) the text transcript of the song lyrics translation was then read and listened on repeat, and then categorized based on the research objectives (3) from the findings of the data, the researcher then critically analyzed it by providing explanations and discussions which relied on the theoretical arguments they referred to; (4) the next step was to make conclusions based on the existing research findings.

\section{DISCUSSION}

\subsection{Translation Method of Dear God in Indonesian Version}

Newmark (1997) grouped translation methods into two large clusters. The first four methods are more emphasized in the source text, namely:

\section{Word-for-word Translation}

The lingual unit in applying this method is at the word level. One by one the words are translated in order, without regard to context. The cultural terms in the source text are translated literally (literally). In the Indonesian version of dear God song. this method is not found. This method is difficult to apply to a song. If translated verbatim, it will confuse the melody. This can be seen from the first verse of this song

(ST)

A lonely road, crossed another cold state line

Miles away from those I love, purpose hard to find

While I recall all the words you spoke to me

Can't help but wish that I was there
Back where I'd love to be, oh yeah (TT)

Jalan sepi di batas kota ini

Jauh dari seseorang yang aku sayangi

Ku terkenang kata yang kau ucapkan

Namun tak bisa membuat ku

kembali padamu

In the first verse of the song, there are 5 lines in ST but in the target text there are only 4 lines. This means no wordfor-word translation is used.

\section{Literal Translation;}

This method is still the same as the previous method verbatim, ie matching is still out of context. The difference lies in the grammatical construction of the source text that is trying to change close to the grammatical construction in the target text. In the Indonesian version of Dear God, this method is not found. Similar to the previous method, the translation in the Indonesian version of Dear God song also does not use this method.

3. Faithful Translation;

Translation with this method tries to establish contextual meaning but still remains bound to the grammatical structure of the source text. This results in a discrepancy with the rules of the target text, especially the translation of cultural terms, so that the results of the translations often feel stiff. In the Indonesian version of the song Dear God, this method is also not found. This method is difficult to apply to a song. If translated using this method, it will mess with the melody.

4. Semantic Translation;

Regarding attachment to the source text, this method is more flexible than the faithful translation method. The term culture is translated so that it's easier for the reader to understand. The aesthetic element of the source text is 
prioritized, but accompanied by a compromise that is still within reasonable limits. In the Indonesian version of the song Dear God semantic translation method is also not found.

The next four methods are more emphasized in the target text, namely:

\section{Adaptation;}

This method is the most free method of translation. That is, the attachment of language and culture to the source text is very thin, almost nonexistent, the attachment is actually closer to the target text. Cultural elements contained in the source text are replaced with cultural elements that are closer and closer to the target audience. The adaptation method proposed by Newmark (1997), which includes the omission of words or Newmark (1997), expressed it in terms of omission and also detected a change in syntactic structure or Newmark called it shift. Because according to Newmark adaptation is "the" freest "form of translation", this method has the freedom to make various efforts so that the translation results can function properly and can be understood by the target language readers.

In translating the Indonesian version of Dear God, this method is widely used by translators, among them:

A lonely road, crossed another cold state line

Miles away from those I love, purpose hard to find

While I recall all the words you spoke to me

Can't help but wish that I was there

Back where I'd love to be, oh yeah (TT)

Jalan sepi di batas kota ini
Jauh dari seseorang yang aku sayangi

Ku terkenang kata yang kau ucapkan

Namun tak bisa membuat ku kembali padamu

The opening lyrics of this song read "A lonely road, crossed another cold state line" and translates it to " Jalan sepi di batas kota ini " in the lyrics of the translation. The lyrics in this translation can be accepted, because the meaning that is conveyed by the source language can be accepted in the target language. But in the lyrics there is omission of the word "Cold". The word Cold here illustrates that in the source language where this song was created has a cold temperature of 6 degrees Celsius. In the source language the word cold is omitted. This is to adjust the actual situation. So that this song still makes sense even though it was sung in the Indonesian version (TT).

The next line of lyrics reads "Miles away from those I love, purpose hard to find" and the target language is translated to " jauh dari seseorang yang aku sayangi." Look back at the disappearance of the lyrics of the translation results. The "when purpose hard to find" section is not translated. So that the focus of the sentence in the source language is the section "Miles away from those I love" which translates to " jauh dari seseorang yang aku sayangi." In equivalent, the results of the translation in this section can be considered acceptable. However, the omission does not change the context of the lyrics of this section because the focus of the words in the source language is still clearly translated, so that with the focus of words successfully translated the context of the initial lyrics can still be implied in the results the translation. 
(ST)

Dear God, the only thing I ask of you

Is to hold her when I'm not around When I'm much too far away We all need that person who can be true to you

But I left her when I found her

And now I wish I'd stayed

'Cause I'm lonely and I'm tired

I'm missing you again, oh no...

Once again

(TT)

*Tuhan .. Hanya satu pintaku padamu

Jagalah dia saat aku jauh dari sisinya

Ku butuhkan orang yang tulus padaMu

Tapi ku tinggalkan dia saat aku berjumpa..

Ku sendiri .. Dan ku lelah

Ku merindukanmu sayangg ..

Dan Lagi

Furthermore, in the lyrics of "Dear God, the only thing I ask of you" is translated to "Tuhan Hanya Satu Pintaku Padamu ". The omission of "dear" to the translated lyrics can be considered as an effort to adjust the translated lyrics into the rhythm structure of the original song. But the omission does not damage the context of the lyrics contained in the source language so it does not cause any shift.

Furthermore, the lyrics "Is to hold her when I'm not around" translates to "Jagalah dia saat aku jauh dari sisinya ". The word "hold" is given the equivalent of "take care". The word "hold" here seems to have various senses, or interpretations. This is because that a word can have a second meaning if it is used in a particular context. "Hold" here is not a word that means "to hold, hold, to grasp", but rather something that means "take care."
Choosing the equivalent of "guard" as the translation is considered acceptable. Because in the culture of the target language the word also has the same various sense. Because the word guard also has meaning of holding, or defending.

Furthermore, in the lyrics of "And now I wish I'd stayed" the translator did not translate this sentence. The author assumes this is done to adjust the rhythm of the song on the original text.

2. Free Translation

The method of free translation prioritizes the content of the source text rather than the structure. Freedom in this method is still limited to freely expressing the meaning of the target text, so it is still limited to the purpose or content of the source text even though the form of the source text has not been raised again.

In the song Dear God found several translations that use this method including:

(ST)

Some search, never finding a way

Before long, they waste away

I found you, something told me to stay

I gave in, to selfish ways

And how I miss someone to hold

When hope begins to fade...

(TT)

Mencari .. tiada ku temukan

Seolah sia-sia

Karena ku tetap bertahan

Menyerah, takkan pernah

Betapa ku merindukan mu di dalam pelukmu

In the third verse of the song Omission 1 line in the verse. In the original lyrics, it costs 6 lines but in the target text there are 5 lines. This is considered in the lyrics of the translation results as an attempt to adjust the translation of the lyrics into 
the rhythm structure of the original song. However, this translation does not damage the context of the lyrics contained in the source language so it does not cause any shift. This is because this translation is more concerned with the contents of the translation rather than the structure that must be in accordance with the source text.

\section{Idiomatic Translation}

Idiomatic translation reproduces 'messages' from the source text but tends to distort the nuances of meaning. This is due to not finding the same idiomatic expression in the target text, so nuance distortion can not be avoided. In translating this song, researchers did not find idiomatic use in the Indonesian version of the song Dear God.

\section{Communicative Translation}

This translation method seeks in such a way as to produce contextual meaning precisely, so that aspects of the language can be accepted and the contents can be directly understood by the target reader.

In translating the Indonesian version of the song Dear God, the translator does not use the communicative translation method. This method seeks to translate contextual meaning in the source text, both linguistic aspects and aspects of its contents, so that it can be accepted and understood by the reader. This method pays attention to the principles of communication, namely the understanding of the reader and the purpose of translation. In addition, communicative translation basically emphasizes message diversion. This method is very concerned about the reader or listener of the target text that does not expect the difficulties and ambiguity in the translated text and is very concerned about the effectiveness of the translation language.
4.2. The Ideology of Translators in

Indonesian Dear God Song

The concept of domestication and foreignization was introduced by Lawrence Venuti (1995) in his book entitled The Translator's Invisibility. This concept is the two basic translation strategies that provide linguistic and cultural guidance. Domestication is a translation strategy that aims to reduce the level of alienation of an original text so that it is comfortable to read by the reader. The translator attempts to reproduce the text so that it is as if the text was indeed written in the target language.

The domestication strategy was criticized because it was considered an ethnocentric reduction of the original text. This strategy forces the speaker into the language of the reader. To prevent this ethnocentric culture of origin discrimination, Venuti offers a second strategy, namely foreignization. According to Venuti (1995: 20), foreignization refers to efforts that emphasize the characteristics of the original text, albeit by confusing cultural codes that apply in the target language.

In addition to maintaining cultural authenticity, foreignization is also considered to contain a spirit of cultural equalization in it. Through this strategy, minority countries will still be able to voice their thoughts in their own unique terms.

From the analysis of the translation done to the lyrics of the song Dear God, it appears that the Indonesian version of the song Dear God tried to make this song as if it were written in Indonesian by eliminating some words and even sentences in the lyrics without changing the song's meaning. As explained earlier, this domestication strategy will have an impact on the loss 
of the original text's uniqueness and make the target culture look superior to the culture from which the original text originated.

However, in translating song lyrics, researchers agree with Eugene Nida's opinion that is concerned with the needs of readers and see that the results of the translation must have a relationship with the culture of the recipient, in this case the culture of the reader (Nida in Rubel and Rosman: 2003: 8). In other words, Nida does not emphasize the uniqueness of the source language, but rather the equality of functions in the native and target languages. That is, the results of the translation must have the closest meaning to the original source.

\section{CONCLUSION}

Translators tend to use translation methods that are oriented to the language of the target text. This can be seen in the song the researcher sees that there is a word disappearance and also a shift in the equivalent and structure of the target language, although not always in all the results of the translation. But if you pay close attention to the context contained in the source language (SL) is still implied in the target language (TL).

In translating the Indonesian version of Dear God, the translator is more concerned with understanding the target language users, and this notion is found from the translation method which tends to use the one proposed by Newmark which is oriented towards the target language. Thus the Indonesian translation version of the song emphasizes more on the ideology of domestication.

\section{REFERENCES}

Agasta, Geofani. (2013). Analisis Teknik Terjemahan Padanan Leksikal Lagu Populer Amerik Dalam Bahasa Jerman. Depok: Universitas Indonesia. Retrieved From

http://www.lib.ui.ac.id/naskahring kas/2016-03/S52720-

Geofani\%20Anggasta

Basil Hatim and Jeremy Munday. (2004). Translation: An Advance Resource Book. London and New York: Routledge.

Carbaugh, D. (1993). Folklore, Cultural Performances, and Popular Entertainments: A Communications- Centered Handbook. Richard Bauman. American Anthropologist, 95(3), 736-737.

http://jurnal.unsil.ac.id/index.php/ jspendidikan/article/view/742

Hoed, B. H. (2006). Penerjemahan dan Kebudayaan. Bandung: Dunia Pustaka Jaya.

House, J. (2000). Linguistic relativity and translation. Current Issues in Linguistic Theory. New Jersey: Prentice Hall.

Jong, Hwayeon dkk. (2016). Prosedur dan Metode Penerjemahan Lirik Lagu dalam Film Frozen. Jurnal Humaniora, 16(2), 14-21. https://ojs.unud.ac.id/index.php/sa stra/article/view/26445/16789

Newmark, P. (1997). Translation Theory and the Theory of Translation. Modelle Der Translation: Models of 
Translation. Festschrift Für Albrecht Neubert.

Rubel, Paula \& Rosman, Abraham.(2003). Introduction: Translation and Athropology. In Rubel, Paula \& Rosman, Abraham (Ed.). Translating Cultures: Perspectives on Translation and Anthropology. New York: Berg

Utari, N.L.A.P.. (2017). Analisis Teknik Penerjemahan dan Kecampingan Gramatikal pada Lirik Lagu AKB48. Jurnal Pendidikan Bahasa Jepang Undiksa,JPBJ. 3(2), 166-178. https://ejournal.undiksha.ac.id/ind ex.php/JJPBJ/article/view/11188/ pdf

Venuti, Lawrence. (1995). The Translator's Invisibility: A History of Translation. London and New York: Routledge.

Avenged SevenFold. Dear God . YouTube. Retrieved December 14, 2019 from https://www.youtube.com/watch $? \mathrm{v}=\mathrm{mzX} 0 \mathrm{rhF} 8$ buo

Avenged SevenFold. Dear God Versi Indonesia. YouTube. Retrieved December 14, 2019 from https://www.youtube.com/watch $? \mathrm{v}=\mathrm{eu} 1 \mathrm{NkcN0zLg}$

Zakrimal. (2019). Translation Shift of Google Translate Program in Translating Sport News on LINE Daily Kompas. Journal Basis. 6(1), 95-104. http://ejournal.upbatam.ac.id/inde x.php/basis/article/view/1049/709 
